\title{
Effect of paddy-straw based Total Mixed Ration (TMR) on milk yield, milk composition and rumen parameters in lactating Red Chittagong cows
}

\author{
N.R. Sarker*, D. Yeasmin, F. Tabassum and M.A Habib \\ Fodder Research and Development Project, Bangladesh Livestock Research Institute (BLRI), Savar, \\ Dhaka
}

\begin{abstract}
This study was carried out for a period of 70 days to investigate the comparative advantages of feeding total mixed ration (TMR) over conventional feeding in Red Chittagong cows (RCC). 15 RCC milking cows were divided into 3 treatment groups in a Completely Randomized Design (CRD). Existing feeding was denoted as control group $\left(\mathrm{T}_{0}\right)$. TMR made with $60 \%$ roughage and $40 \%$ concentrate in the forms of block $\left(\mathrm{T}_{1}\right)$ and mash $\left(\mathrm{T}_{2}\right)$ were provided to other treatment groups. DM and CP intake was significantly $(\mathrm{p}<0.001)$ higher in $\mathrm{T}_{1}$ group. Body weight gains were not differed significantly, but better milk yield $(\mathrm{p}<0.001)$ and milk components were observed in TMR feeding groups. Except ADF, other nutrient digestibility in TMR group were significantly $(\mathrm{p}<0.05)$ better than $\mathrm{T}_{0}$. Total volatile fatty acids $(\mathrm{p}<0.01)$ and ammonia-nitrogen $(\mathrm{p}<0.05)$ in TMR feeding groups were significantly higher than $\mathrm{T}_{0}$. Considering overall observation, TMR either in block or mash performed better than control.
\end{abstract}

(Key words: Dairy cows,TMR, rumen fermentation, milk yield, milk composition)

\section{Introduction}

Livestock plays a vital role in the natural resource-based livelihood of the vast majority of the population living in developing countries. Availability of animal feed is one of the greatest constraints to the expansion of the livestock industry in developing countries. Animals of the country mainly depend on rice straw for their nutrition and its contribution to livestock feeds is more than $90 \%$ of feed energy available in ruminant's diet. An estimate shows that there is a shortage of $40 \%$ dry matter, $43 \%$ digestible crude protein. Another estimate shows that there is a shortage of $50 \%$ green fodder and $90 \%$ concentrates in the country (BBS 2004). The availability of straw is more than that of our requirements. Due to lack of effective management of these resources, unfortunately they are being burnt in some areas of Bangladesh, causing environmental pollution. Most of the crop residues are high in silica and lignin preventing the action of digestive enzymes leading to reduced nutrient digestibility. Hence, suitable processing methods have to be employed to enhance the utilization of crop residues. Various systems of feeding have been developed for optimum utilization of feed resources for sustainable livestock production. The most promising method proved to be best is the incorporation of crop residues in total mixed rations. The feeding value of these crop residues can be increased by incorporating them into total mixed

*Corresponding author: sarkernr62@yahoo.com

Bang. J. Livs. Res. Special Vol. 21-25, 2018: P. 69-81, ISSN 1022-3851 
rations (TMR) by fortifying them with required nutrient (Sharma et al., 2010). TMR can be defined as a mixture of both the roughages and the concentrate ingredients, formulated and mixed thoroughly to form a balanced feed. It can form a sole feed source for a 24 hour period and can be offered adlibitum for best results. The merits of complete feed are related to stable rumen environment for optimum fermentation with minimal fermentation losses and fluctuation in the release of ammonia, better utilization of rumen non-protein nitrogen, and stabilization of the acetate to propionate ratio which favors normal fat synthesis and enhancement of utilization of low-grade roughages (Konka et al., 2010; Lailer et al., 2005). Complete feed avoids selective refusal of unpalatable dietary portions, thus has provision for incorporation of unconventional feed resources to economize animal feeding. Thus, Paddy straw based TMR will help to minimize roughage shortage of the country that helps to optimize milk production and cow's health. Therefore the present study was designed to know the effect of paddy straw based TMR on nutrient intake, milk yield, milk composition, nutrient utilization and rumen environment of Red Chittagong cows

\section{Materials and Methods}

\section{Duration, dietary treatments and layout of the experiment}

The research was conducted at Bangladesh Livestock Research Institute (BLRI), Savar Dhaka, Bangladesh for a period of 70 days from 31th May to 8th August, 2016. According to Complete Randomized Design (CRD) a total of 15 early lactating Red Chittagong cows were selected considering their same average initial milk yield and divided into 3 treatment. One group was considered as control $\left(\mathrm{T}_{0}\right)$ and fed conventional feed that supplied to the animal at the farm. This 100 $\mathrm{kg}$ conventional diet composed with $82 \mathrm{~kg}$ napier-3 silage, $5 \mathrm{~kg}$ wheat bran, $2 \mathrm{~kg}$ wheat broken, $1.5 \mathrm{~kg}$ kheshari bran, $4.5 \mathrm{~kg}$ soybean meal, $2 \mathrm{~kg}$ maize crushed, $0.5 \mathrm{~kg}$ salt, $2.5 \mathrm{~kg}$ DCP. Another two groups were fed TMR ( $60 \%$ roughages: $40 \%$ concentrate), in which one was fed TMR block $\left(\mathrm{T}_{1}\right)$ and another TMR mash $\left(\mathrm{T}_{2}\right)$. Rice straw was chosen for the roughage component of TMR and which was chopped into 1.5-2.00 inch by a chopper machine before preparation of TMR. Rice straw along with other ingredients were analyzed (Table 1) to determine the DM. After nutritional evaluation, all the concentrate ingredients (40\%) were well mixed manually and then those mixture were properly mixed with roughage $(60 \%)$ and made in a block form by pressing manually and a gross weight of about $5 \mathrm{~kg}$. The $100 \mathrm{~kg}$ TMR mixture composed of $60 \mathrm{~kg}$ rice straw and 40 $\mathrm{kg}$ concentrate mixture $(25 \mathrm{~kg}$ soybean meal, $10 \mathrm{~kg}$ molasses, $1 \mathrm{~kg}$ wheat bran, $1 \mathrm{~kg}$ khesari bran, $2.5 \mathrm{~kg}$ di-calcium phosphate and $0.5 \mathrm{~kg}$ salt.)

\section{Feeding and management of animals}

All experimental animals were drenched with anti-helminthes (Albendazole) prior to the commencement of the feeding trial. Cows were stall fed with zero grazing. Every day required amount of molasses and water solution was properly mixed with previously made TMR mash and provided twice daily (once in the morning at $8.00 \mathrm{am}$ and rest in the afternoon at $4.00 \mathrm{pm}$ ). Fresh, clean and safe drinking water was available for the animals. 
Table 1. Nutrient and dietary composition of different experimental feed

\begin{tabular}{|c|c|c|c|c|c|}
\hline Feed Ingredient & DM\% & $\mathrm{CP} \%$ & $\begin{array}{l}\text { Amount in } \\
100 \mathrm{~kg}\left(\mathrm{~T}_{0}\right)\end{array}$ & $\begin{array}{l}\text { Amount in } \\
100 \mathrm{~kg}\left(\mathrm{~T}_{1}\right)\end{array}$ & $\begin{array}{c}\text { Amount in } 100 \\
\mathrm{~kg}\left(\mathrm{~T}_{2}\right)\end{array}$ \\
\hline $\begin{array}{l}\text { BLRI Napier }-3 \\
\text { silage }\end{array}$ & 20.3 & 10.2 & 82 & - & - \\
\hline Rice straw & 88.8 & 4.6 & - & 60 & 60 \\
\hline Wheat bran & 90.0 & 14.9 & 5 & 1 & 1 \\
\hline Wheat broken & 89.1 & 12.1 & 2 & - & - \\
\hline Kheshari bran & 91.6 & 12.4 & 1.5 & 1 & 1 \\
\hline Soybean meal & 90.5 & 43.7 & 4.5 & 25 & 25 \\
\hline Maize crushed & 90.0 & 8.5 & 2 & & \\
\hline Molasses & 80.0 & 4.5 & - & 10 & 10 \\
\hline Salt & 99.5 & - & 0.5 & 0.5 & 0.5 \\
\hline DCP & 98.0 & - & 2.5 & 2.5 & 2.5 \\
\hline \multicolumn{6}{|c|}{ Nutrients in diet } \\
\hline $\mathrm{DM}(\%)$ in diet & - & - & 34.8 & 49.8 & 50.1 \\
\hline $\mathrm{CP}(\%)$ in diet & - & - & 15.3 & 15.8 & 15.4 \\
\hline $\begin{array}{l}\text { ME supply } \\
(\mathrm{MJ} / \mathrm{D} / \text { cow })\end{array}$ & & & 48.3 & 49.1 & 47.9 \\
\hline
\end{tabular}

\section{Digestibility trial}

In order to determine digestibility of supplied feed, a conventional digestibility trial was carried out at the middle of the feeding trial considering 7 days adjustment period and 7 days collection periods. During that period, daily feed intake, feces and urine voided were recorded and collected individually. At the end of the collection period the feces were composites together and then proximate components of each of the samples were analyzed in Animal Nutrition Laboratory at BLRI.

\section{Milk yield and milk analysis}

Individual morning and evening milk yield of lactating cows were recorded daily. Milk samples were collected from each cow at 15 days interval and were analyzed for fat, protein, lactose, SNF and total ash contents by milk analyzer (Lactostar, Funk Gurbar). Fat corrected milk yield (FCMY) were calculated by using following formula of $4 \% \mathrm{FCM}=0.4$ $\mathrm{x}$ milk yield $(\mathrm{kg})+15 \mathrm{x}$ fat yield $(\mathrm{kg})$ as stated by Gains (1928).

\section{Rumen liquor collection}

At the end of the trial, rumen liquor was collected at 3, 6, 9, 12, 24 and 36 hours intervals post feeding by using stomach tube having $0.15 \mathrm{~mm}$ internal diameter and 150 $\mathrm{cm}$ long plastic tube. The stomach tube was moistened and animal's mouth was opened by placing thumb in the region without teeth. 
The tube was then passed over the back of tongue and enters into the esophagus. A vaccum pump was used to apply suction to draw ruminal fluid. The fluid was obtained by lowering the animals head until fluid runs from the tube. Approximately, $50 \mathrm{ml}$ of rumen liquor was collected from two animals in each group. The sucked fluid was filtered by a cheese cloth. The $\mathrm{pH}$ was measured immediately after collection, using the digital PH meter. Then, samples were stored at $-18^{\circ} \mathrm{C}$ for subsequent laboratory analysis. Total volatile fatty acids (TVFAs), total nitrogen $(\mathrm{TN})$, ammonia nitrogen $\left(\mathrm{NH}_{3}-\mathrm{N}\right)$, non-protein nitrogen $(\mathrm{NPN})$, and protein nitrogen (PN) were also measured from the samples collected from those hours by using following procedure.

\section{Determination of TVFA}

Equal quantities of 5\% oxalic acid and 10\% potassium oxalate were mixed just before use to prepare Oxalic acid-potassium oxalate buffer. TVFA of all serum rumen liquor (SRL) sample was determined by micro Kjeldahl digestion of a $1 \mathrm{ml}$ sample with $5 \mathrm{ml}$ of oxalic acid + potassium oxalate buffer and set for distillation. After distillation $80 \mathrm{ml}$ of distillate was collected and then titrated against N/100 NaOH up to reach pink color at the end point. The amount of TVFA was calculated by using the following formula as recommended by Barnelt and Reid., (1957) as TVFA $\mathrm{ml}$ equivalent $/ 100 \mathrm{ml}$.

TVFA $(\mathrm{ml} \mathrm{eq} / 100 \mathrm{ml})=\mathrm{ml}$ of $\mathrm{N} / 100 \mathrm{NaOH}$ used x 100

If it is $2.5 \mathrm{ml}$ then $2.5 \times 100=25 \mathrm{ml} \mathrm{eq} / 100 \mathrm{ml}$

\section{Determination of $\mathbf{T N}$}

\section{a) Digestion}

Organic nitrogen + conc. $\mathrm{H}_{2} \mathrm{SO}_{4} \frac{\mathrm{CuSO}_{4}}{{\mathrm{~K} 2 \mathrm{SO}_{4}}_{4}}-\left(\mathrm{NH}_{4}\right)_{2} \mathrm{SO}_{4}$

\section{b) Distillation}

$\left(\mathrm{NH}_{4}\right)_{2} \mathrm{SO}_{4}+2 \mathrm{NaOH}-2 \mathrm{NH}_{3}+\mathrm{NaSO}_{4}+$ $2 \mathrm{H}_{2} \mathrm{O}$

$3 \mathrm{NH}_{2}+\mathrm{H}_{3} \mathrm{BO}_{3}-\left(\mathrm{NH}_{4}\right)_{3} \mathrm{BO}_{3}$

\section{c) Titration}

$2\left(\mathrm{NH}_{4}\right)_{3} \mathrm{BO}_{3}+3 \mathrm{H}_{2} \mathrm{SO}_{4}-3\left(\mathrm{NH}_{4}\right)_{2} \mathrm{SO}_{4}+$ $\left(\mathrm{NH}_{4}\right)_{3} \mathrm{BO}_{3}$

For the calculation of $\mathrm{TN}$ in rumen liquor, 10 $\mathrm{ml}$ of SRL with $5 \mathrm{ml}$ of concentrated $\mathrm{H}_{2} \mathrm{SO}_{4}$ and $5 \mathrm{gm}$ of digestion mixture $\left(0.5 \mathrm{~g} \mathrm{CuSO}_{4}\right.$ and $4.5 \mathrm{~g} \mathrm{~K}_{2} \mathrm{SO}_{4}$ ) was added. Then it was kept stand for $10 \mathrm{~min}$ to soak the sample and set for digestion at $100^{\circ} \mathrm{C}$. After completing digestion it turned blue, then it was cooled down. Distilled water was added and stirred properly to make up the volume $100 \mathrm{ml}$ in the volumetric flask. About $5 \mathrm{ml}$ of aliquot was taken and the acid digest was made strongly basic with $10 \mathrm{ml}$ of $40 \% \mathrm{NaOH}$ solution and ammonia released was distilled into a boric acid solution and titrated against 1/100 N $\mathrm{H}_{2} \mathrm{SO}_{4}$.

$\mathrm{TN}(\mathrm{mg} / 100 \mathrm{ml}$ of $\mathrm{RL})=$

Volume of $\frac{N}{10} \mathrm{H}_{2} \mathrm{SO}_{4} * 0.00014 * 100 * 100 * 1000$

$5 \mathrm{ml}$ rumen liquor sample $*$ Digested aliquot $(5 \mathrm{ml})$

\section{Determination of NH3-N}

$\mathrm{NH}_{3}-\mathrm{N}$ concentration of the SRL sample was determined as by $5 \mathrm{ml}$ of sample was taken in a centrifuge tube and equal amount of $0.2 \mathrm{~N}$ $\mathrm{HCl}$ was added, and then it was centrifuged in a centrifuge machine at 3000 RPM for 10 minutes. Afterwards $2 \mathrm{ml}$ of aliquot was taken in the Micro Kjeldhal apparatus and $5 \mathrm{ml}$ of $0.1 \mathrm{~N} \mathrm{NaOH}$ was added. Thereafter, 50-60 ml was steam distillated into $2 \%$ boric acid solution and then it was titrated against 
$\mathrm{N} / 100 \mathrm{H}_{2} \mathrm{SO}_{4}$. where $\mathrm{NH}_{3}-\mathrm{N}$ unit is $\mathrm{mg} / 100$ $\mathrm{ml}$. $\mathrm{NH}_{3}-\mathrm{N}$ was calculated by using the following formula

$$
\begin{aligned}
& (\mathrm{mg} / 100 \mathrm{ml})= \\
& \frac{\text { Volume of } \frac{N}{100} \mathrm{H}_{2} \mathrm{SO}_{4} * 0.00014 * 1000 * 100}{\text { Aliquot }(1)}
\end{aligned}
$$

\section{Determination of PN and NPN}

For the calculation of $\mathrm{PN}$ in rumen Liquor, 5 $\mathrm{ml}$ of SRL was taken and $5 \mathrm{ml}$ of $20 \%$ TCA was added and then it was centrifuged at $3000 \mathrm{rpm}$ for 10 minutes. The supernatant was discarded. Then $5 \mathrm{ml}$ of $10 \%$ TCA was added again and kept for 10 minutes, centrifuged at $3000 \mathrm{rpm}$ for 10 minutes and the supernatant was discarded. Then $5 \mathrm{ml}$ of conc. $\mathrm{H}_{2} \mathrm{SO}_{4}$ was added to the pellet with the digestion mixture. After complete digestion $100 \mathrm{ml}$ volume was made in the volumetric flask. Then $10 \mathrm{ml}$ of aliquot and $10 \mathrm{ml}$ of 40 $\% \mathrm{NaOH}$ was set in the distillation chamber. Here $50 \mathrm{ml}$ of distillate was collected into 10 $\mathrm{ml} \mathrm{2 \%}$ boric acid solution when it turns from pink to green color. Finally, it was titrated against $\mathrm{N} / 100 \mathrm{H}_{2} \mathrm{SO}_{4}$ as NPN and $\mathrm{PN}$ mg/100 $\mathrm{ml}$. The NPN was calculated from PN by using the following formula

$\mathrm{NPN}=\mathrm{TN}-\mathrm{PN}$

\section{Chemical analysis}

The feed samples, leftover and faeces were analyzed by the method of AOAC (2005) for determination of DM, CP, OM and Ash, while, ADF and NDF by Van Soest et al., (1991).

\section{Statistical analysis}

There were three treatments with 5 replications (animals) in each group. Thus the design of the experiment was completely randomized design (CRD). The data were analyzed using the "SPSS 17.0" statistical program using one way ANNOVA. Duncan's Multiple Range Test (DMRT) was done to compare among the treatment means for various parameters. Significant difference was declared when $\mathrm{p}<0.05$.

\section{Results and Discussion}

\section{Feed intake}

Feed intakes of animals of different groups are shown in Table 2. Total DM intake, CP intake, and \% DM intake on live weight was significantly higher in $\mathrm{T}_{1}$ than other two groups. The result was in agreement with Lailer et al. (2010) and Sehgal and Jha (2008) who described that densified TMR block significantly improves DM intake. The results of the present study were also in accorded with the findings of Verma et al. (1996), Nagpal et al. (2005), Gupta et al. (2006), Lade et al. (2007) and Sharma et al. (2010). Bargo et al. (2002) studied on the performance of Holstein Friesian cows feeding with three different diets such as pasture plus concentrate, pasture plus partial TMR and TMR (non-pasture) and found significantly higher DM intake for cows fed TMR which is coincided with this study. They found highest milk yield, fat and protein content in cows fed only TMR which is in agreement with this study. The CP intake differed significantly $(p<0.001)$ among animals of different treatment groups. The highest CP intake was observed in $T_{2}$ (fed TMR mash) and lowest in $T_{1}$. The higher CP intake in TMR block at the present study strictly supported by the findings of Chander (2011). Though, animals of all treatment groups were supplied diet containing same \% of CP but variation of $\mathrm{CP}$ intake could be due to variation of DM intake of certain diet. 
Table 2 Feed intake of animal for different treatment groups

\begin{tabular}{lcccc}
\hline Parameters & \multicolumn{4}{c}{ Treatment group ( mean \pm SE $)$} \\
\cline { 2 - 5 } & $\mathrm{T}_{0}$ & $\mathrm{~T}_{1}$ & $\mathrm{~T}_{2}$ & $\begin{array}{c}\text { Significance } \\
\text { level }\end{array}$ \\
\hline Fresh feed intake (kg/day) & $16.8^{\mathrm{c}} \pm 0.1$ & $14.6^{\mathrm{b}} \pm 0.1$ & $14.1^{\mathrm{a}} \pm 0.2$ & $* * *$ \\
DM intake (kg/day) & $3.3^{\mathrm{a}} \pm 0.03$ & $4.5^{\mathrm{c}} \pm 0.03$ & $4.3^{\mathrm{b}} \pm 0.06$ & $* * *$ \\
CP intake (kg/day) & $0.4^{\mathrm{a}} \pm 0.004$ & $0.5^{\mathrm{c}} \pm 0.002$ & $0.5^{\mathrm{b}} \pm 0.007$ & $* * *$ \\
\% DM intake on LW & $1.6^{\mathrm{a}} \pm 0.1$ & $2.0^{\mathrm{b}} \pm 0.09$ & $1.8^{\mathrm{ab}} \pm 0.07$ & $* *$ \\
\hline
\end{tabular}

DM- Dry matter; LW- Live weight of animal; ${ }^{* * *} \mathrm{p}<0.001,{ }^{* *} \mathrm{p}<0.01$, means with superscripts within the same row differed significantly.

\section{Milk yield}

Milk production of cows for different treatment groups are shown in Table 3 which varied significantly $(\mathrm{p}<0.001)$ among groups. Highest average daily milk yield (both whole and fat corrected) was observed in $\mathrm{T}_{1}$ and lowest in $\mathrm{T}_{0}$ group, although there was no significant difference between $\mathrm{T}_{1}$ and $\mathrm{T}_{2}$ groups. with three different diets such as pasture plus concentrate, pasture plus partial TMR and TMR (non-pasture) and found significant difference in milk yield that is in the line of the current study. Hundal et al. (2004) conducted an experiment with densified TMR block and found no significant changes for milk yield which is contradicted with this study. This contradiction may be due to

Table 3. Milk yield of different treatment groups

\begin{tabular}{lcccc}
\hline Parameter & $\mathrm{T}_{0}$ & $\mathrm{~T}_{1}$ & $\mathrm{~T}_{2}$ & $\begin{array}{c}\text { Significance } \\
\text { level }\end{array}$ \\
\hline Initial daily average milk yield (ltr) & $2.7 \pm 0.3$ & $2.7 \pm 0.2$ & $2.7 \pm 0.2$ & $\mathrm{NS}$ \\
Final average dailymilk yield(ltr) & $2.7^{\mathrm{a}} \pm 0.02$ & $3.0^{\mathrm{b}} \pm 0.02$ & $2.9^{\mathrm{b}} \pm 0.03$ & $* * *$ \\
FCMY (ltr/d) (4\% fat) & $2.9^{\mathrm{a}} \pm 0.1$ & $3.2^{\mathrm{b}} \pm 0.05$ & $3.1^{\mathrm{b}} \pm 0.04$ & $*$ \\
\hline
\end{tabular}

NS-non significant, ${ }^{* * *}$-p $<0.001$ means with uncommon superscript within the same row differed significantly.

Higher milk yield of cows fed TMR block at the present study strongly supported by the findings of Teshome et al. (2017). Lailer et al. (2010) reported that TMR significantly improves milk production performances of animal. The result also agreed with by Walli (2015) who conducted a study with straw based densified TMR block and got a positive effect on milk production. Bargo et al. (2002) studied performance of milk production of Holstein Friesian cows feeding difference of breed, formulation of feed, feed ingredients, stage of lactation and environment.

\section{Milk composition}

Changes of milk compositions of cows for different treatment groups are given in Table 4. The table shows that milk fat, protein and lactose differed significantly $(\mathrm{p}<0.05)$ among treatment groups, while not differed for SNF. Apparently, highest milk fat was observed in 
$\mathrm{T}_{2}$ group and lowest in $\mathrm{T}_{0}$ group. However, there were no differences between $\mathrm{T}_{0}$ and $\mathrm{T}_{1}$ and between $T_{1}$ and $T_{2}$. Although, milk protein was higher in $\mathrm{T}_{1}$ than $\mathrm{T} 0$ and $\mathrm{T}_{2}$, but did not differ with $\mathrm{T}_{2}$. reported no differences in live weight changes for roughage and concentrates ratio of 60:40.

Though, animals were more or less mature and all were at early lactation stage and no

Table 4. Milk composition of different treatment groups

\begin{tabular}{lcccc}
\hline Parameter & $\mathrm{T}_{0}$ & $\mathrm{~T}_{1}$ & $\mathrm{~T}_{2}$ & $\begin{array}{c}\text { Significance } \\
\text { level }\end{array}$ \\
\hline Fat (\%) & $4.5^{\mathrm{b}} \pm 0.1$ & $4.9^{\mathrm{ab}} \pm 0.1$ & $5.0^{\mathrm{a}} \pm 0.1$ & $*$ \\
Protein (\%) & $3.8^{\mathrm{b}} \pm 0.1$ & $4.1^{\mathrm{a}} \pm 0.03$ & $4.0^{\mathrm{a}} \pm 0.03$ & $* * *$ \\
Lactose (\%) & $5.7^{\mathrm{b}} \pm 0.1$ & $6.0^{\mathrm{a}} \pm 0.05$ & $5.8^{\mathrm{ab}} \pm 0.04$ & $*$ \\
SNF (\%) & $10.9 \pm 0.08$ & $11.0 \pm 0.1$ & $10.9 \pm 0.05$ & NS \\
\hline
\end{tabular}

NS- non significant ${ }^{* * *}$-p $<0.001$ means with uncommon superscript within the same row differed significantly.

Bargo et al. (2002) in their study found highest milk fat and protein percentages in cows fed TMR compared to cows fed partial TMR and pasture plus concentrate which is in agreement with this study. It is evident that there are lots of genetic and non-genetic factors responsible for variability of milk composition like breed, heredity, diet, time and frequency of milking, season etc. animals were pregnant so, emphasize was given for increasing milk yield, thus body weight gain is not expected in such condition. However, all dietary treatments were subjected to constant the level of roughage and concentrate ratio (60:40), and in such situation difference of weight gain is unexpected among treatment groups. This is agreed with Sporndly (1986) who concluded

Table 5. Changes of animal's body weight for different treatment groups

\begin{tabular}{lcccc}
\hline \multirow{2}{*}{ Parameters } & \multicolumn{4}{c}{ Treatment group } \\
\cline { 2 - 5 } & $\mathrm{T}_{0}$ & $\mathrm{~T}_{1}$ & $\mathrm{~T}_{2}$ & Significance \\
& (Control) & (TMR block) & (TMR mash) & level \\
\hline Total body weight gain $(\mathrm{kg})$ & $12.2 \pm 3.5$ & $16.3 \pm 1.3$ & $33.7 \pm 1.8$ & $\mathrm{NS}$ \\
Daily weight gain $(\mathrm{kg})$ & $0.1 \pm 0.05$ & $0.2 \pm 0.01$ & $0.4 \pm 0.02$ & NS \\
\hline
\end{tabular}

LW=Live weight of animal; NS-non significant $(\mathrm{p}>0.05)$; means with uncommon superscript within the same row differed significantly.

\section{Body weight changes}

Total body weight gain at the end of the experiment is given in Table 5. Although, there were changes of body weight, but differences were not significant $(p>0.05)$ among cows of different groups. The result is in agreement with Mahal et al. (1997) who that changing the ratio of roughage to concentrate from 62:38 to 50:50 significantly increased live weight gain. But, the result is contradicted with Bargo et al. (2002) who found significantly higher body weight gain for cows fed TMR. 


\section{Nutrient digestibility}

Digestibility of nutrients in feed supplied to animals of different groups is illustrated in Table 6. From this table it is clear that except ADF digestibility DM, OM, CP, ash and NDF digestibility significantly $(\mathrm{p}<0.05)$ differed among treatment groups of animals. In all cases, digestibility of the said components in supplied feed was significantly higher in $\mathrm{T}_{1}$ than those of other two groups. On the other hand, ADF digestibility did not differ significantly among groups. al. (2004) and Shojaeian and Thakur (2007) reported that the increase DM digestibility appeared to be associated with higher NDF digestibility which confirms by this study. The values obtained for $\mathrm{CP}$ digestibility of TMR in the present study were in agreement with the values of $62.22 \%, 61.40 \%$ and $59.65 \%$, respectively $(\mathrm{p}>0.05)$ for maize stover, red gram straw and black gram straw based complete rations (Konka et al., 2015). The values of NDF obtained in this study were also similar to the values (53.23 to

Table 6. Nutrient digestibility (\%) for different treatment groups

\begin{tabular}{ccccccc}
\hline \multirow{2}{*}{$\begin{array}{c}\text { Nutrient } \\
\text { digestibility (\%) }\end{array}$} & \multicolumn{3}{c}{ Treatment } & & SE & $\begin{array}{c}\text { Significance } \\
\text { level }\end{array}$ \\
\cline { 2 - 4 } & $\mathrm{T}_{0}$ & $\mathrm{~T}_{1}$ & $\mathrm{~T}_{2}$ & & $*$ \\
$\mathrm{DM}$ & $51.3^{\mathrm{c}}$ & $63.8^{\mathrm{a}}$ & $61.2^{\mathrm{b}}$ & & 1.4 & $*$ \\
$\mathrm{CP}$ & $52.4^{\mathrm{b}}$ & $63.5^{\mathrm{a}}$ & $60.5^{\mathrm{a}}$ & & 1.5 & $*$ \\
$\mathrm{OM}$ & $54.01^{\mathrm{b}}$ & $66.5^{\mathrm{a}}$ & $65.1^{\mathrm{a}}$ & & 1.5 & $*$ \\
$\mathrm{Ash}$ & $33.2^{\mathrm{b}}$ & $50.8^{\mathrm{a}}$ & $50.05^{\mathrm{a}}$ & & 2.3 & $\mathrm{NS}$ \\
$\mathrm{ADF}$ & 53.7 & 58.8 & 56.3 & & 1.2 & $*$ \\
NDF & $52.7^{\mathrm{b}}$ & $57.6^{\mathrm{a}}$ & $57.1^{\mathrm{ab}}$ & & 1.0 & $*$ \\
\hline
\end{tabular}

Values are means of five fold samples; SE: standard error; means withinthe same row with different superscripts $(\mathrm{a}-\mathrm{c})$ differ significantly $(\mathrm{p}<0.05)$.

The result is comparable with the findings of Konka et al. (2015) who conducted an experiment with three different crop residues based complete rations (crop residue and concentrate with ratio of 60:40 in buffalo at India) and found significant difference of in vitro DM digestibility. They reported DM digestibility from $55.45 \%$ to $58.59 \%$ which closely agrees with this study. This result was also similar with the findings of Lailer et al. (2010) and Sehgaland Jha (2008) who described that densified TMR block significantly improves DM digestibility. The higher digestibility of DM obtained in TMR block might be due to more soluble carbohydrates in the form of starch which agrees well by Sardar et al. (1996). Wang et
$56.33 \%$ ) found by Konka et al. (2015). But the values of ADF in this study were higher than the values (42.10 to $44.73 \%$ ) obtained by Konka et al. (2015). It was also reported that digestibility of complete feeds can be enhanced by the additions of relatively small quantities of specific nutrients such as protein or soluble carbohydrates (Khan et al., 2010).

\section{Rumen fermentation}

Table 7. shows the rumen fermentation parameters in different sample collection period after feeding of different treatment groups. The result showed that rumen $\mathrm{pH}$ had no significant differences $(p>0.05)$ in different hour of incubation in different 
treatment groups. The result of the present findings was similar with the observation of Williams and Christian (1959). They reported no corresponding changes in rumen $\mathrm{pH}$ value in different treatment groups.
There were significant differences $(\mathrm{p}<0.01)$ observed in TVFA in different periods of post feeding $(0,3,6,12,24$ and $36 \mathrm{~h})$ in different treatment groups. The concentration of TVFA was increasing after $3 \mathrm{~h}$ post feeding, reached

Table 7. Rumen fermentation parameters in different treatment groups according to different post feeding sampling hours

\begin{tabular}{|c|c|c|c|c|c|c|}
\hline \multirow[t]{2}{*}{ Parameters } & \multirow{2}{*}{$\begin{array}{c}\text { Period } \\
\text { (hour) }\end{array}$} & \multicolumn{4}{|c|}{ Dietary treatments } & \multirow{2}{*}{$\begin{array}{l}\text { Level } \\
\text { of Sig }\end{array}$} \\
\hline & & $\mathrm{T}_{0}$ & $\mathrm{~T}_{1}$ & $\mathrm{~T}_{2}$ & SEM & \\
\hline \multirow[t]{5}{*}{$\mathrm{P}^{\mathrm{H}}$} & 3 & 6.5 & 6.3 & 6.6 & 2.6 & NS \\
\hline & 6 & 4.5 & 4.4 & 4.5 & 2.6 & NS \\
\hline & 12 & 6.4 & 6.4 & 6.6 & 2.6 & NS \\
\hline & 24 & 6.6 & 6.4 & 6.5 & 2.6 & NS \\
\hline & 36 & 6.5 & 6.6 & 6.5 & 2.6 & NS \\
\hline VFA (mM/100 & 3 & 10.5 & 11.5 & 11.5 & 4.5 & $* *$ \\
\hline \multirow[t]{4}{*}{$\mathrm{ml})$} & 6 & 15.6 & 11.3 & 9.1 & 5.9 & $* *$ \\
\hline & 12 & 18.5 & 17.5 & 17.0 & 6.8 & $* *$ \\
\hline & 24 & 11.0 & 12.9 & 11.5 & 4.6 & $* *$ \\
\hline & 36 & 15.5 & 18.5 & 16.5 & 6.8 & ** \\
\hline \multirow[t]{5}{*}{$\mathrm{TN}(\mathrm{g} / 100 \mathrm{ml})$} & 3 & 1.9 & 1.7 & 1.4 & 0.6 & NS \\
\hline & 6 & 2.3 & 2.0 & 2.1 & 0.8 & NS \\
\hline & 12 & 1.9 & 2.5 & 2.1 & 0.8 & NS \\
\hline & 24 & 1.5 & 1.8 & 2.6 & 0.8 & NS \\
\hline & 36 & 1.8 & 1.9 & 1.8 & 0.7 & NS \\
\hline \multirow[t]{5}{*}{$\mathrm{NH}_{3}-\mathrm{N}(\mathrm{g} / 100 \mathrm{ml})$} & 3 & 13.9 & 14 & 12.8 & 5.5 & $*$ \\
\hline & 6 & 10.6 & 11.6 & 11.1 & 4.5 & * \\
\hline & 12 & 9.3 & 9.6 & 9.3 & 3.8 & $*$ \\
\hline & 24 & 17.6 & 23.6 & 23.9 & 8.8 & $*$ \\
\hline & 36 & 9.0 & 9.1 & 8.7 & 3.6 & $*$ \\
\hline \multirow[t]{5}{*}{$\mathrm{PN}(\mathrm{g} / 100 \mathrm{ml})$} & 3 & 1.0 & 1.1 & 1.1 & 0.4 & NS \\
\hline & 6 & 1.2 & 1.1 & 1.0 & 0.3 & NS \\
\hline & 12 & 0.9 & 0.9 & 1.0 & 0.6 & NS \\
\hline & 24 & 1.4 & 1.9 & 1.8 & 0.6 & NS \\
\hline & 36 & 1.0 & 1.4 & 1.3 & 0.5 & NS \\
\hline \multirow[t]{5}{*}{ NPN (g/100ml) } & 3 & 0.9 & 0.6 & 0.3 & 0.4 & NS \\
\hline & 6 & 1.1 & 0.9 & 1.1 & 0.5 & NS \\
\hline & 12 & 1.1 & 1.0 & 1.6 & 0.1 & NS \\
\hline & 24 & 1.2 & 0.1 & 0.1 & 0.1 & NS \\
\hline & 36 & 0.8 & 0.4 & 0.5 & 0.2 & NS \\
\hline
\end{tabular}

$*_{*}^{*}$ - $<<0.01, *$-p $<0.05$ NS-non significant ( $>0.05$ ); means with uncommon superscript within the same row differed significantly. VFA-Volatile Fatty Acid, TN- Total Nitrogen, NH3-NAmmonia Nitrogen, PN- Protein Nitrogen, NPN- Non Protein Nitrogen. 
a maximum level at $12 \mathrm{~h}$ and then decreased at $24 \mathrm{~h}$ and increasing thereafter as shown in Fig.1. This result is highly corrugated with the findings of Reid et al. (1957). The concentration level of TVFA depends on ruminal microbial activity, hydrolysis of protein and NPN (Venkanna et al., 1997). TVFA production is an indicator of carbohydrate digestion especially the crude fiber (Girdhar and Balaraman, 2005).

The changes of Total Nitrogen (TN) concentrations in different treatment groups ( $p>0.05$ ) were found to be increased slowly up to $6 \mathrm{~h}$ post feeding and then decreased gradually ( $>0.05)$. The $\mathrm{TN}$ at $0-3 \mathrm{~h}$ and at $36 \mathrm{~h}$ post feeding for any of the treatment groups was almost similar. The highest level of PN (Protein Nitrogen) concentration was obtained at $24 \mathrm{~h}$ post feeding, although the changes for period of fermentation and treatment groups were not significant. The highest level of NPN concentration was obtained at $12 \mathrm{~h}$ post feeding, although the changes for period of fermentation and treatment groups were not significant.

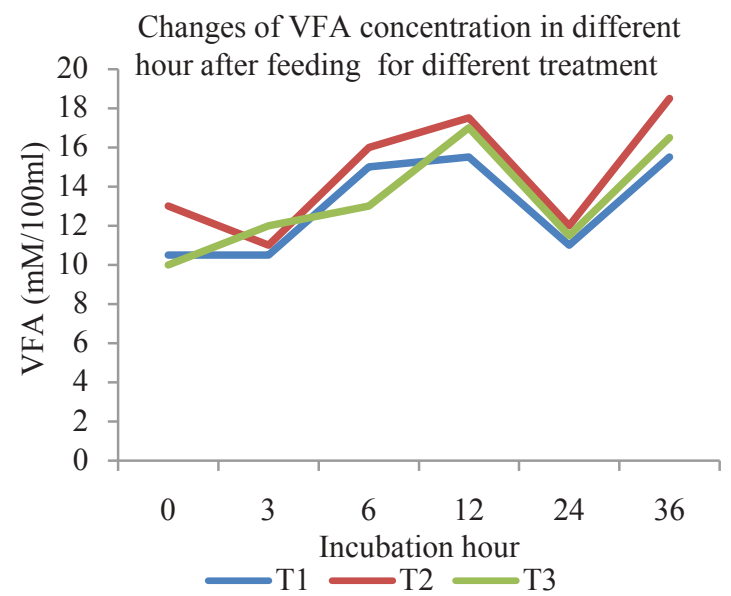

Figure. 1 Changes of TVFA concentration in different fermentation period
$\mathrm{NH}_{3}-\mathrm{N}$ is regarded as the most important nitrogen source for microbial protein synthesis in the rumen (Bryant, 1974) and the level in the rumen is usually high when feeds are more digestible (Erdmen et al., 1986). $\mathrm{NH}_{3}-\mathrm{N}$ concentrations differed significantly $(p<0.05)$ for periods of fermentation and treatment groups. The changes of $\mathrm{NH}_{3}-\mathrm{N}$ concentrations in different treatment groups were found to be decreased gradually towards $12 \mathrm{~h}$ post feeding, but again increasing and reached a maximum level at $24 \mathrm{~h}$ and decreasing thereafter (Fig-2). According to Carvalho et al. (1997), the reduction in ruminal NH3-N concentration can be explained by the increase in energy availability in the rumen, allowing higher use of ammonia for microbial growth, with consequent reduction in ammonia loss due to synchronization in the carbohydrates and protein degradation. TMR seems to have provided better condition for rumen fermentation and nutrient digestion, which are well documented in the literature (Lee et al., 2000; Russell and Rychlik, 2001).

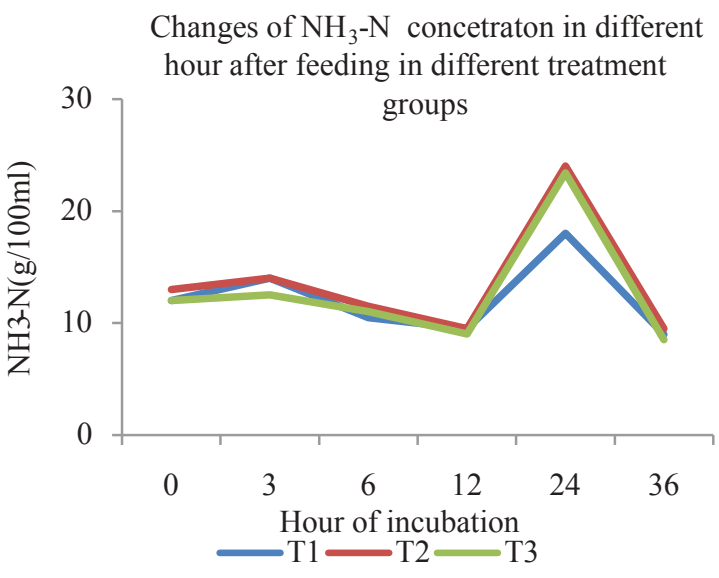

Figure. 2 Changes of $\mathrm{NH}_{3}-\mathrm{N}$ concentration in different fermentation period 
Table 8. Economic analysis for different treatment groups

\begin{tabular}{llllll}
\hline Treatment & $\begin{array}{l}\text { Feed intake } \\
(\mathrm{kg} / \mathrm{d})\end{array}$ & $\begin{array}{l}\text { Feed cost } \\
\text { /day }\end{array}$ & $\begin{array}{l}\text { Milk } \\
\text { price/day }\end{array}$ & Profit/day & BCR \\
\hline $\mathrm{T}_{0}$ & 24.93 & 176 & 234 & 58 & 1.32 \\
$\mathrm{~T}_{1}$ & 14.40 & 187 & 252 & 65 & 1.35 \\
$\mathrm{~T}_{2}$ & 14.01 & 182 & 244 & 62 & 1.34 \\
\hline
\end{tabular}

(Considering milk price @BDT 60.0/ltr.)

\section{Economic analysis}

After completion of the feeding trial, economic analysis was also conducted based on benefit cost ratio (BCR) of three treatment represented in Table 8 . The net profit over feed cost was higher in $T_{1}$ cows fed TMR block compared to $\mathrm{T}_{0}$ those cows fed on conventional ration.

This result is similar with earlier reports on feeding of jowar, wheat and bajra straw based complete rations to cattle and buffalo that reduced the cost of feeding animals for milk production, compared to conventional ration Lailer et al. (2010), Kishore et al. (2013).

\section{Acknowledgement}

The Authors are grateful to the authority of "Fodder Research Development Project" implemented by Bangladesh Livestock Research Institute, for providing technical support to complete this research work.

\section{Conclusion}

The results of the present experiment revealed that the ration fed in $T_{1}$ and $T_{2}$ are superior compared to that fed in $\mathrm{T}_{0}$ in terms of milk yield, milk composition (fat, protein and lactose), the digestibility of different nutrients, TVFA and $\mathrm{NH}_{3}-\mathrm{N}$ production. However, performance of the ration was not different between TMR block and TMR mash. TMR block may be more suitable during scarcity period because it is easy to handle and required low space for storage.

\section{References}

AOAC. 2007. Official methods of Analysis, 18th edition. Association of Official Analytical chemists, Washington DC.

Bargo, F., Muller, L.D., Delahoy, J.E. and Cassidy, T.W. 2002. Performance of high producing dairy cows with three different feeding systems combining pasture and total mixed rations. J. Dairy Sci., 85: 2948-2963.

Barnett, A.J.G. and Reid, R.L. 1957. Studies on the production of volatile fatty acids from grass by rumen liquor in an artificial rumen. The Volatile fatty acid production from fresh grass. J. Agric.Sci., 48:315

BBS 2004. Bangladesh Bureau of Statistics, Statistics Division, Ministry of Planning, Government of the Peoples' Republic of Bangladesh, Dhaka.

Bryant, M.P. 1974. Nutritional features and ecology of predominant anaerobic bacteria of the intestinal tract. Am. J. Clin. Nutr. 27:1313 $-1319$.

Carvalho, A.S. 1997. Ammonia nitrogen determination in plant material. Netherlands $\mathrm{J}$. Agr. 22:3-5

Chander, M. 2011. Chaff cutters and fodder chaffing: A simple technology worth adoption. In H.P.S. Makkar, ed. Proceedings of FAO E-Conference on, Successes and 
failures with animal nutrition practices and technologies in developing countries, pp. 133-136.

Erdman, R.A., Proctor G.H. and Vandersall J.H. 1986. Effect of rumen ammonia concentration on in situ rate and extent of digestion of feedstuffs. J. Dairy Sci. 69:2312-2320.

Gains, W.L. 1928. The energy basis of measuring milk yield in dairy cows. University of Lllinois. Agriculture Experiment Station. Bulletin No. 308

Gridhar, N. and Balaraman, N. 2008. Feeding of maize fodder based total mixed ration having different levels of energy and protein to lactating crossbred cows. Indian J. Dairy Sci., 61(6): 435-440.

Gupta, R.B., Tiwari, D.P. and Kumar, A. 2006. Effect of feeding complete ration vis-à-vis conventional ration on nutrient utilization and rumen metabolism in crossbred cattle. Indian J. Anim. Sci., 76: 55-60.

Hundal, J.S., Gupta, R.P., Wadhwa, M. and Bakshi, M.P.S. 2004. Effect of feeding total mixed ration on the productive performance of dairy cattle. Animal Nutrition and Feed Technology, 4: 179-186.

Khan, S.R., Sigh, S.K. and Vishal, M. 2010. Effect of feeding complete rations on the performance of lactating crossbred cows. Indian J. Anim. Nutr., 27:261-264.

Kishore, K.R., Kumar, D.S., Ramana, J.V. and Rao, E.R. 2013. Field trial of maize stover based complete ration vis-à-vis conventional ration on lactation performance in graded murrah buffaloes. Animal Science Reporter. 7(4):123-127.

Konka, R.K., Kumar D.S., Ramana, J.V., Ravi, A. and Rao, E.R. 2010. Fermentation pattern in Murrah buffalo bulls fed crop residue based complete rations vis-a-vis conventional feeding system. Anim. Nutr. Feed Technol. 16 (1):
171-179.

Konka, R.K., Dhulipalla, S.K., Jampala, V.R., Arunachalam, R., Pagadala, E.P. and Elineni, R.R. 2015. Evaluation of crop residue based complete rations through in vitro digestibility. J. Adv. Vet. Anim. Res., 2(1): 64-68. DOI: 10.5455/javar.2015.b50.

Lade, M.H., Tiwari, D.P. and Kumar, A. 2007. Effect of feeding complete ration vis-à-vis conventional ration with and without green fodder on nutrient utilization and lactation performance in crossbred cows.Indian J. of Anim. Sci., 77:1026-1033.

Lailer, P.C.; Dahiya, S.S.; and Chauhan, T.R. 2005.Complete feed for livestock concept, present status and future trend: A review. Indian J. Anim. Sci.,75(1):84-91.

Lailer, P.C., Dahiya, S.S.; Madan, L.; Lal, D. 2010. Effect of complete feed blocks on growth performance of Murrah male calves. Indian J. of Anim. Nutr., 27: 220-223.

Lee, S.S., Ha, J.K. and Cheng, K.J. 2000. Relative contributions of bacteria, protozoa and fungi to in vitro digestion of orchard grass cell walls and their interaction. Appl. Env. Microbiol. 66:3807-3813.

Mahal, G.S., Randhawa, S.S., Singh, B. and Singh, B. 1997. Effect of feeding different forage to concentrate ratios on nutrient utilization and productive performance of crossbred cows. Indian J. Anim. Prod. and Manag., 13:93-97.

Nagpal, A.K., Arora, M., Singh, G.P. 2005. Nutrient utilization of gram straw (Cicerarietinum) based complete feed blocks in calves. Indian J. Anim. Nutr., 75: 64-68.

Reid, R.L., Hogan, J.P. and Briggs, P.K. 1957. The effect of diet on individual volatile fatty acids in the rumen of sheep, with particular reference to the effect of low rumen $\mathrm{pH}$ and adaptation on high starch diets. Aust. J. Agr. Res. 8: 691-710. 
Russell, J.B., Rychlik, J.L. 2001. Factors that alter rumen microbial ecology. Sci. Res. pub. 292:1119-1122.

Sardar, P., Kewalramani, N. and Kaur, H. 1996. Influence of G-5 supplementation on rumen fermentation and in vitro dry matter digestibility. Indian J. Indig. Med., 18:77-81.

Sehgal, J.P. and Jha, P. 2008. Efficient utilization of fibrous crop residues in ruminants.In Proceedings of the national seminar on emerging opportunities for commercialization in dairying, pp.73-82.NDRI, Karnal, India.

Sharma, D., Tiwari D.P. and Modal, B.C. 2010. Performance of crossbreed female calves fed complete ration as mash or block vis-à-vis conventional ration. Ind. J. Anim. Sci., 80: 556-560.

Shojaeian, K. and Thakur, S.S. 2007. Effect of exogenous fibrolytic enzymes supplementation to substrates containing different roughage: concentrate ratios on in vitro rumen fermentation, DM and NDF degradability. Indian J. Dairy Sci., 60: 94-101.

Sporndly, R. 1986. Intake and production response of dairy cows to a fixed ratio of silage to cereals, fed as separate feeds, blended or ensiled together. In: Ensiling of blended grass and grain and its utilization by dairy cows.

Tareque, A.M.M. and Saadullah, M. 1988. Feed availability requirements for animal and current patterns of utilization in Bangladesh. In: Non-conventional feed Resources and Fibrous Agricultural residues (ed. C. Devendra). Proceedings of consultation held in Hisar, India. PP. 116-130.
Teshome, D; Fita, L; Feyissa, F; Kitaw, G; Wndatir, Z. 2017. Effect of Total Mixed Ration (TMR) on dry matter intake, milk yield and composition of early lactating Jersey cows. J. Bio., Agr. and Healthcare.7 (9):19-24

Van Soest P.J., Robertson J.B. and Lewis B.A. 1991 Methods for Dietary Fiber, Neutral Detergent Fiber, and Non starch Polysaccharides in Relation to Animal Nutrition. J. Dairy Sci. 74:3583-3597.

Venkanna, P., Reddy, M.R., and Reddy, G.V.N. 1997. Rumen fermentation pattern on complete diets based on dry mixed grass or cotton seed hulls in cross bred bulls. Indian J. anim. Nutr., 14: 245-249.

Verma, A.K., Mehra, U.R., Dass, R.S., Singh, A. 1996. Nutrient utilization by Murrah buffaloes (Bubalusbubalis) from compressed complete feed blocks.Anim. Feed Sci. Technol., 59: 255-263.

Walli, T.K. 2008b. Complete feed block - An effective feeding technology for efficient utilization of our limited feed resources. In Proceedings of the regional animal nutrition conference, pp.1-3, Animal Nutrition Society of India, Tirupati.

Wang, Y., Spratling, B.M., Zobell, D.R., Wiedmeier, R.D., McAllister, T.A. 2004. Effect of alkali pretreatment of wheat straw on the efficacy of exogenous fibrolytic enzymes. J. Anim. Sci., 82: 198-208.

Williams, V.J., Christian, K.R. 1959. Concentrations of end products and morphological types of rumen bacteria in silage fed sheep.New Zealand J.Agr.Res., 2:387-393. 